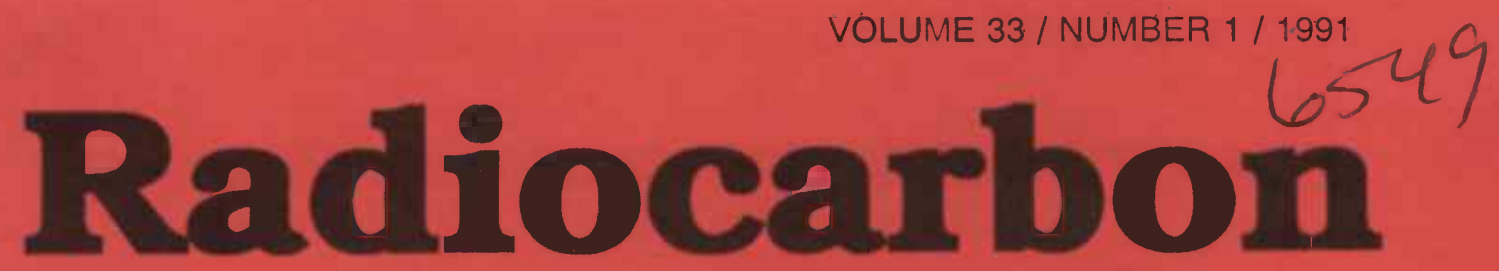

An International Journal of Cosmogenic Ișotope Research

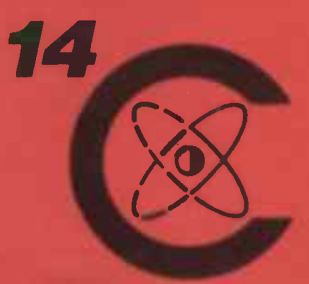

\title{
Editor
}

AUSTIN LONG

Managing Editor

RENEE S KRA

\section{A'ssistant Editor}

FRANCES D' MOSKOVITZ

QC

798

03

A4B

SCI-CFMR

Department of Geosciences

The University of Arizona

4.717 East Ft Lowell Road

Tucson, Arizona 8571,2 
RADIOCARBON

An International Journal of Cosmogenic Isotope Research

Editor: AUSTIN LONG

Managing Editor: RENEE S KRA

Assistant Editor: FRANCES D MOSKOVITZ

Published by

Department of Geosciences

The University of Arizona

Published three times a year at The University of Arizona, Tucson, AZ 85712. (1) 1991 by the Department of Geoscierices, The University of Arizona.

Subscription rate $\$ 94.50$ (for institutions), $\$ 63.00$ (for individuals), $\$ 31.50$ (for students with proper identification), which includes sales tax. Foreign postage is extra: A complete price list, including Proceedings of International Conferences, appears in the back of this issue.

Back issues and price lists may be obtained from the office of RADIOCARBON.

All correspondence and manuscripts should be addressed to the Managing Editor, RADIOCARBON, Department of Geosciences, The University of Arizona, 4717 East Ft Lowell Road, Tucson, AZ 85712. Tel: (602) 881-0857; BITNET: C14@ARIZRVAX; Fax: (602) 881-0554.

Offprints. The minimum offprint order for each article will be 100 copies without covers. No offprints will be furnished free of charge unless page charges are paid. The cost of additional copies will, of course, be greater if the article is accompanied by plates involving unusual expense. Copies will be furnished with a printed cover giving the title, author, volume, page and year, when specially ordered.

Page charges. Each institution sponsoring research reported in a technical paper or a date list, will be asked to pay a charge of $\$ 80.00$ per printed page. Institutions or authors paying such charges will be entitled to 100 free offprints without covers. No charges will be made if the author indicates that the author's institution is unable to pay, and payment of page charges on an article will not in any case be a condition for its acceptance. Reduced rates will be in effect for some special issues.

Missing issues will be replaced without charge only if claim is made within three months (six months for India and Australia) after the publication date. Claims for missing issues will not be honored if absence results from failure by the subscriber to notify the Journal of an address change.

Illustrations should include explanation of symbols used. Copy that cannot be reproduced cannot be accepted. Whenever possible, reduce figures for direct publication. Line drawings should be in black India ink on white drawing board, tracing cloth, or coordinate paper printed in blue and should be accompanied by clear ozalid or reduced photographs for use by the reviewers. Photographs should be positive prints. Figures (photographs and line drawings) should be numbered consecutively through each article, using arabic numerals. All measurements should be given in SI (metric units). Tables may be accepted as camera-ready copy.

Citations. A number of radiocarbon dates appear in publications without laboratory citation or reference to published date lists. We ask that laboratories remind submitters and users of radiocarbon dates to include proper citation (laboratory number and date-list citation) in all publications in which radiocarbon dates appear.

Radiocarbon Measurements: Comprehensive Index, 1950-1965. This index covers all published ${ }^{14} \mathrm{C}$ measurements through Volume 7 of $R A D I O C A R B O N$, and incorporates revisions made by all laboratories. It is available at $\$ 20.00$ per copy.

List of laboratories. Our comprehensive list of laboratories appears annually. We are expanding the list to include additional laboratories and scientific agencies with whom we have established contacts. The editors welcome more information on these or other scientific organizations. We ask all laboratory directors to provide their telephone, telex and fax numbers as well as their Email addresses. Changes in names or addresses, additions or deletions should also be reported to the Managing Editor.

https://doi.org/10. 
Vol 33, No. 1

RADIOCARBON

FROM THE EDITOR

40 And Still Going Strong

Austin Long

CONTENTS

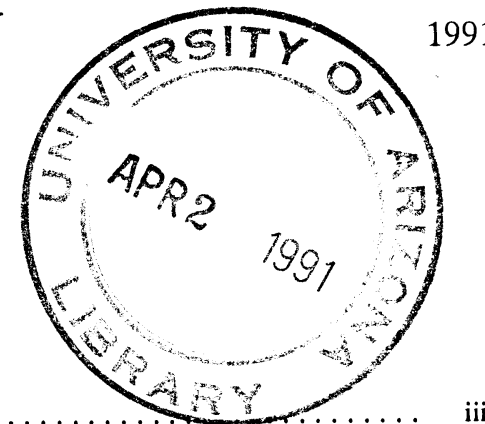

\section{ARTICLES}

Scintillation Cocktail Optimization for ${ }^{14} \mathrm{C}$ Dating Using the Packard 2000CA/LL and 2260XL

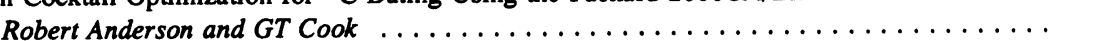

Gas Proportional Versus Liquid Scintillation Counting, Radiometric Versus AMS Dating

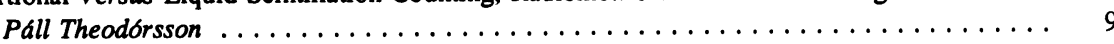

A Late Quaternary Stratigraphic Framework for Eastern Mediterranean Sapropel S1 Based on

AMS ${ }^{14} \mathrm{C}$ Dates and Stable Oxygen Isotopes

SR Troelstra, GM Ganssen, Klaas van der Borg and AFM de Jong . . . . . . . . . 15

The Radiocarbon Laboratory at the University of Barcelona

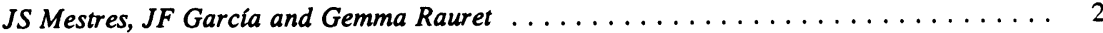

Two Early Sites of Eastern Beringia: Context and Chronology in Alaskan Interior Archaeology Jon Erlandson, Rudy Walser, Howard Maxwell, Nancy Bigelow, John Cook

Ralph Lively, Charles Adkins, Dave Dodson, Andrew Higgs and Janette Wilber

\section{DATE LISTS}

BM British Museum Natural Radiocarbon Measurements XXII

Janet Ambers, Keith Matthews and Sheridan Bowman ................

CU Charles University, Prague Radiocarbon Measurements I

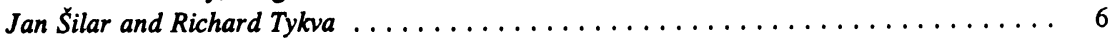

HAR Harwell Radiocarbon Measurements IX

$A J$ Walker, $A W$ Young, $R S$ Keyzor and $R L$ Otlet $\ldots \ldots \ldots \ldots \ldots \ldots \ldots$

HAR Harwell Radiocarbon Measurements X

AJ Walker, $A W$ Young and $R L$ Otlet $\ldots \ldots \ldots \ldots \ldots \ldots \ldots \ldots \ldots \ldots$

LOD $\quad$ Lódź Radiocarbon Dates III

Andrzej Kanwiszer and Pawet Trzeciak

R University of Rome Radiocarbon Dates XVII

Marisa Alessio, Lucia Allegri, Salvatore Improta, Giorgio Belluomini

Cesarina Cortesi, Luigia Manfra and Bruno Turi . .

UD Udine Radiocarbon Laboratory Date List III

Franco Calligaris, Stefano Colonnello, Adriano del Fabbro and

Serena Perrone

W Radiocarbon Dates for Lava Flows and Pyroclastic Deposits on São Miguel, Azores

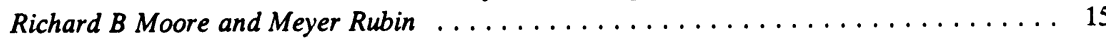

RADIOCARBON UPDATES 


\section{ASSOCIATE EDITORS}

For Accelerator Physics

\section{DAVID ELMORE ROBERT E M HEDGES ERLE NELSON}

For Archaeology
ANDREW MOORE

MICHAEL B SCHIFFER

For Atmospheric Sciences

GEORGE A DAWSON

KUNIHIKO KIGOSHI

DAVID C LOWE

For Geochemistry

PAVEL POVINEC

MINZE STUIVER

For Geophysics

G E KOCHAROV

WILLEM G MOOK

For Ice Studies

HAROLD W BORNS, JR

ULRICH SIEGENTHALER

For Oceanography

EDOUARD BARD

ELLEN R M DRUFFEL

For Paleobotany

CALVIN J HEUSSER
West Lafayette, Indiana

Oxford, England

Burnaby, British Columbia, Canada

Woodbridge, Connecticut

Tucson, Arizona

Tucson, Arizona

Auckland, New Zealand

Tokyo, Japan

Lower Hutt, New Zealand

Bratislava, Czechoslovakia

Seattle, Washington

Leningrad, USSR

Groningen, The Netherlands

Washington, $D C$

Orono, Maine

Berne, Switzerland

Palisades, $N Y$

Gif-sur-Yvette, France

Woods Hole, Massachusetts

Tuxedo, New York 